\title{
Non-random mortality of Baltic cod larvae inferred from otolith hatch-check sizes
}

\author{
Peter Grønkjær*, Michael Schytte
}

Institute of Biological Sciences, Dept. of Marine Ecology, University of Aarhus, Finlandsgade 14, DK-8200 Aarhus N, Denmark

\begin{abstract}
Recent evidence suggests that otolith size at hatch may reflect maternal (e.g. egg size and quality) or intrinsic (bioenergetic) factors influencing growth and survival of larval fish. In this field study, the hatch-check sizes of 133 Baltic cod larvae were examined with regard to larval age, vertical distribution and instantaneous protein growth rates. Larvae with small hatch-checks died around Day 12 to 13, whereas larvae surviving past Day 20 all had hatch-checks close to or larger than the overall mean. Furthermore, there were significant differences between hatch-check sizes of larvae residing at hatching depth $\left(>45 \mathrm{~m}\right.$, mean hatch check size $\left.=261 \mu \mathrm{m}^{2}\right)$ and larvae that had migrated towards more optimal feeding depths $\left(\leq 45 \mathrm{~m}\right.$, mean $=301 \mu \mathrm{m}^{2}$ ). There was a weak, but significant, positive correlation between hatch-checks sizes and instantaneous protein growth rates inferred from RNA/DNAratios of 37 larvae. This correlation improved when we excluded yolk-sac larvae. The differences in otolith hatch-check sizes between larval groups could not be attributed to differences in the environment during egg development. Thus, maternal or intrinsic factors controlling otolith size at hatch may influence the survival of Baltic cod larvae.
\end{abstract}

KEY WORDS: Baltic cod - Otolith hatch-check size $\cdot$ Vertical migration - Growth $\cdot$ Survival

\section{INTRODUCTION}

Most temperate marine fish are highly fecund. However, their progeny subsequently experience high mortality during the early life stages, leaving only a small fraction of the potential recruits to survive until the juvenile or adult stage (Bailey \& Houde 1989, Heath 1992). Most theories invoked to explain the success of the survivors, and to characterise them and their environment, have not been substantiated by strong field evidence (review by Leggett \& Deblois 1994). Hitherto, most studies of survival have focused on variations in mortality rates thought to emanate from fluctuations in the environment, or differential exposure to the environment. However, attention is also now being directed towards maternal (e.g. egg size and quality) and intrinsic (bioenergetic) factors in the belief that they may

\footnotetext{
- Present address: Dept. of Biology, BioSciences Complex Queen's University, Kingston K7L 3N6, Canada.

E-mail: fiskerp@biology.queensu.ca
}

partly determine the patterns of mortality observed through their effect on larval hatching size, metabolism, growth rate and viability (Buckley et al. 1991, Vallin \& Nissling 1995, Chambers \& Leggett 1996, Korhola et al. 1996, Letcher et al. 1996).

Otolith hatch- and first-feeding checks are 2 larval characteristics with potential to link the survivors to maternal or intrinsic factors. These checks are left on the otolith, presumably due to physiological stress (Campana \& Neilson 1985), thereby marking the size of the otolith at hatch and first-feeding, respectively. Miller et al. (1999) have investigated the relationships between egg diameter, larval and otolith size at hatch in cod. They found (1) a significant relationship between lapilli area and standard length at hatch, and (2) a significant relationship between lapilli area and the residuals from an egg diameter standard length at hatch model. Although the predictive ability of the first relationship was low, these findings suggest that analysis of hatch-checks may link larvae with egg size, and to some degree, larval size and, hence, maternal effects. 


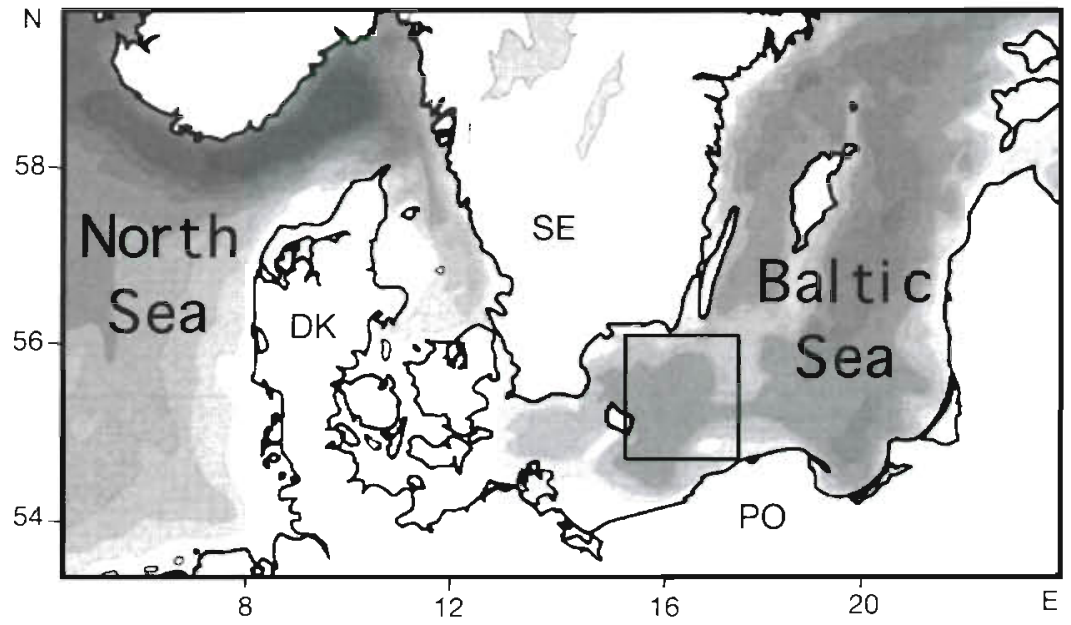

Fig. 1. The Baltic sea. The Bornholm Basin is marked with a square face, where they are able to enhance their nutritional condition (Grønkjær et al. 1997). It has been argued that this migration can only be undertaken by viable, large larvae with strong swimming capabilities due to the rapid sinking of larvae in the low density surface water (Gronkjær \& Wieland 1997). These supenor larvae may be identified by the size of their hatch-check.

In this study, we examine the otolith hatch-check sizes of Baltic cod larvae in relation to age, vertical distribution, and growth rates calculated on the basis of RNA/DNA-ratios, to identify possible correlations with survival through the early larval stages.
Otolith size may also reflect intrinsic or bioenergetic factors. Studies on salmonids have shown otolith size to be poorly correlated with fish size at emergence, but more so with metabolic rate and competitiveness (Mosegaard 1990, Titus \& Mosegaard 1991, Metcalfe et al. 1992). Check size was also found to be significantly correlated with fish size after $3 \mathrm{mo}$, indicating that salmonids with large first-feeding checks have a high growth potential (Metcalfe et al. 1992).

Recently, Meekan \& Fortier (1996) found evidence that juvenile cod surviving a winter with strong sizeselective mortality had larger hatch-checks than the population from which they originated, which led them to suggest that the factors underlying fast growth were present at hatch, i.e. of intrinsic or maternal origin. These findings correspond well with theoretical and empirical evidence suggesting that fast growing marine fish larvae may have a higher chance of survival than the average individual (e.g. Bailey \& Houde 1989, Houde 1989, Campana 1996), and suggest an approach for characterising survivors.

Thus, there are indications that the potential for fast growth in fish larvae may be related to maternal or intrinsic factors, that this potential can be reflected in otolith size at hatch or first-feeding, and that these fast growing larvae have a higher than average probability of survival.

Baltic cod eggs hatch in the region of the permanent halocline (>55 m), where the eggs are neutrally buoyant at a salinity of 12.3 to 18.2 psu depending on egg characteristics, such as size and lipid content (Nissling et al. 1994 a). Successful development of the eggs is limited to depths with salinity higher than 11 psu and oxygen content in excess of $2 \mathrm{ml} \mathrm{O}_{2} \mathrm{I}^{-1}$ (Plikshs et al. 1993, Wieland et al. 1994). At first-feeding, the larvae actively migrate towards more optimal feeding conditions near the sur-

\section{MATERIALS AND METHODS}

The cod larvae were caught during 4 studies of the vertical distribution of cod larvae in the Bornholm Basin, Baltic Sea, the major spawning area of Baltic cod (Fig. 1). The studies (2 to 3 May, 1 to 3 June and 12 to 13 July 1994 and 19 to 20 May 1995) were part of monthly ichthyoplankton surveys carried out by the Institute for Marine Research, Kiel, Germany, covering the peak occurrence of Baltic cod larvae.

A $1 \mathrm{~m}^{2}$ BIOMOC multiple opening/closing net (mesh size $335 \mu \mathrm{m}$ ) was employed in order to sample larvae in $5 \mathrm{~m}$ depth intervals from the bottom (approximately $85 \mathrm{~m}$ ) to the surface (for sampling details see Grønkjær \& Wieland 1997). The zooplank ton, including cod larvae, were fixed in buffered (pH 8) $4 \%$ formaldehyde-seawater immediately after sampling. After approximately 3 wk fixation, the cod larvae were sorted and transferred to $70 \%$ ethanol. Some of the larvae were taken from samples intended for analysis of nutritional condition (RNA/ DNA-ratios). These larvae were sorted on board and frozen in liquid nitrogen. Description of the RNA and DNA analyses performed on these larvae and calculation of instantaneous protein growth rates can be found in Gronkjær et al. (1997).

Data on the hydrographic regime (temperature, salinity, conductivity and oxygen content) were obtained using a ME OTS $1500 \mathrm{CTD} / \mathrm{O}_{2}$ on the sampling stations.

All larvae were measured to the nearest $0.1 \mathrm{~mm}$ before removal of the lapillar and sagittal otoliths. The otoliths were removed under a dissecting microscope using a polarised light source and fine insect needles mounted on handles. After cleansing in demineralised water, the 4 otoliths were mounted on a single glass 
slide with cyanoacrylate glue in a manner allowing for distinction between the 2 otolith types as well as left and right otoliths.

Only lapillar otoliths (unpolished) with unambiguous hatch-checks were included in the analysis. The hatch-check was normally associated with a wide $(0.5$ to $1.5 \mu \mathrm{m}$ ) bright (translucent) zone and we defined the hatch-check as the first prominent discontinuous zone within this. This definition of the hatch-check was supported by examination of laboratory reared North Sea cod larvae (Grønkjær et al. 1997, Grønkjær unpubl.).

Otolith analyses were performed on the basis of digitised pictures taken using a Photometrics Image Point CCD camera connected to a Zeiss Axiovert microscope and an Apple Macintosh PowerPC. All pictures were taken at 1000 times magnification yielding a pixel resolution of $0.1 \mu \mathrm{m} \times 0.1 \mu \mathrm{m}$. On-screen magnification was approximately $\times 5600$. The subsequent measurements were done semi-automatically using the image analysis software NIH/Object Image. The hatch-check circumference was drawn by the investigator. The software then calculated the area as well as the longest and shortest axis of an ellipse surrounding the hatch-check. Seven otoliths with very irregular hatch-checks were not used in the analyses. Measurement error was estimated by picking 24 otoliths at random and measuring them twice 1 wk apart. The mean coefficient of variation (CV) on the area was $2.8 \pm 0.4 \%$ (SE). Mean asymmetry (ratio of the smallest to the largest area) between the left and right hatch-check area was $0.87 \pm 0.01(\mathrm{SE}, \mathrm{n}=45$ ). Hatchcheck area of larvae with 2 readable otoliths was taken as the simple mean.

Because unpolished otoliths of young larval cod are almost spherical, optical phenomena may bias measurements on the hatch-checks, and do so in a size dependent manner. We tested whether this was likely to occur in our study by polishing and remeasuring 23 otoliths covering our entire size range. A paired $t$-test did not show any significant difference between the polished and unpolished otoliths with regard to hatchcheck area $(t=1.79, \mathrm{df}=22, \mathrm{p}=0.088)$. In addition, the differences in hatch-check size that did exist between polished and unpolished otoliths were not correlated with otolith size (Spearman Rank Correlation, $\mathrm{r}_{\mathrm{s}}=0.12$, $\mathbf{n}=23, p=0.582$ ), hence hatch-check measurements based on unpolished otoliths seem to be unbiased.

The age of the larvae was determined from the lapillar otoliths. The number of increments were counted and each otolith count was weighted with regard to the confidence put in the reading (Stevenson \& Campana 1992).

In the comparison of hatch-check areas and larval lengths of fish taken above and below $45 \mathrm{~m}$, data were

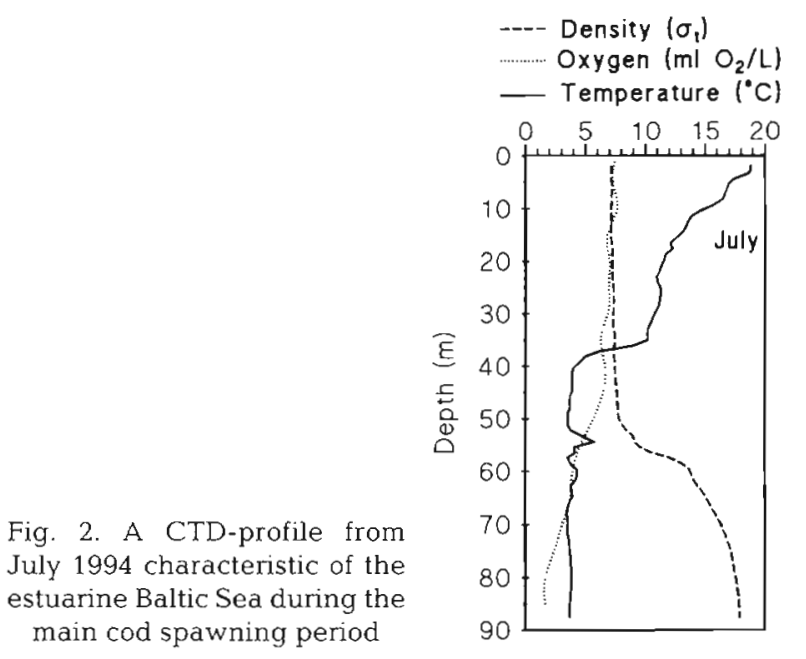

aggregated to yield a mean value for each net deployed (sampling unit).

\section{RESULTS}

A CTD profile from July 1994 characteristic of the hydrographic regime during the main cod spawning season is shown in Fig. 2. Halocline depth increased and the oxygen content in the sub-halocline layers decreased from May 1994 onwards, confining successful egg development to a narrow depth range in May 1995. The oxygen and temperature conditions at the depth of the centre of mass of late stage eggs (60 to $63 \mathrm{~m} ; \mathrm{K}$. Wieland pers. comm.) is shown in Table 1 . The scenario seen in 1994 is typical of the seasonal development of the hydrographic regime in the Bornholm Basin. The relatively high temperature and low oxygen content in spring 1995 were due to the absence of substantial saltwater inflow from the North Sea during the winter of 1994/95.

Otoliths were extracted from a total of 282 cod larvae. Of these, 133 larvae aged 5 to $37 \mathrm{~d}$ had clear hatch-checks (Table 1). The mean area, and longest and shortest hatch-check axis $( \pm \mathrm{SE})$ were $296 \pm 4 \mathrm{um}^{2}$,

Table 1. Number of larvae analysed, median age, and temperature and oxygen content at depth of centre of mass for hatching eggs $(60 \mathrm{~m})$

\begin{tabular}{|lcccc|}
\hline Date & $\begin{array}{c}\text { No. of } \\
\text { larvae }\end{array}$ & $\begin{array}{c}\text { Median } \\
\text { age } \\
\text { (days) }\end{array}$ & $\begin{array}{c}\text { Temp- } \\
\text { erature } \\
\left({ }^{\circ} \mathrm{C}\right)\end{array}$ & $\left(\mathrm{ml} \mathrm{O}_{2} \mathrm{l}^{-1}\right)$ \\
\hline 2 to 3 May 1994 & 33 & 10 & 2.9 & 7.8 \\
1 to 3 June 1994 & 32 & 10 & 3.2 & 6.3 \\
12 to 13 July 1994 & 42 & 9 & 3.7 & 4.5 \\
19 to 20 May 1995 & 26 & 11 & 4.0 & 4.8 \\
\hline
\end{tabular}




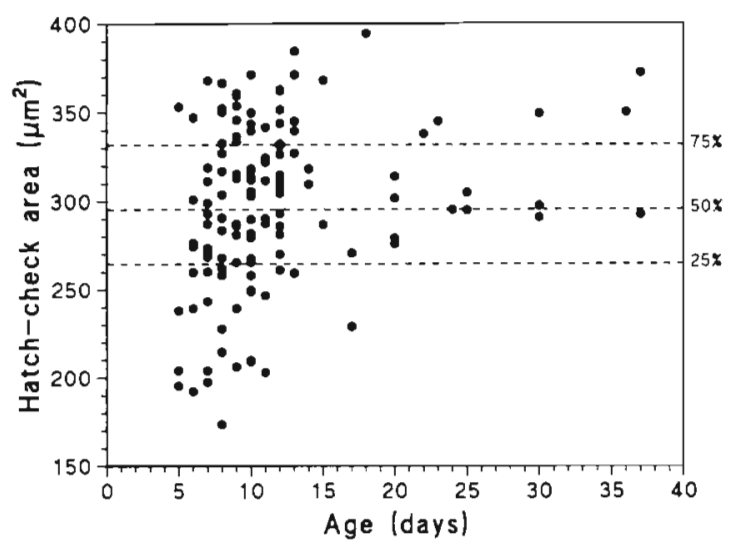

Fig. 3. The hatch-check area of 133 cod larvae aged 5 to $37 \mathrm{~d}$ The median as well as the 25 and $75 \%$ quartile is shown

$21.3 \pm 0.2 \mu \mathrm{m}$ and $17.7 \pm 0.2 \mu \mathrm{m}$, respectively. The otolith areas were normally distributed (KolmogorovSmirnov test with Lillefors significance correction, $K-S=0.048, \mathrm{df}=133, \mathrm{p}>0.2$ ).

The distribution of hatch-check areas with regard to larval age is shown in Fig. 3. There was a trend of larger hatch-check areas with age. Larvae with small hatch-checks were rare after Day 12 to 13 . The trend seen in these combined data was apparent on all cruises, i.e. there was no preponderance of small or large hatch-checks from any one cruise.

Examining the larvae aged $13 \mathrm{~d}$ and younger (Fig. 4), we found that there were significant differences in the distribution of hatch-check areas between larvae that were found at the optimum feeding conditions in the sur-

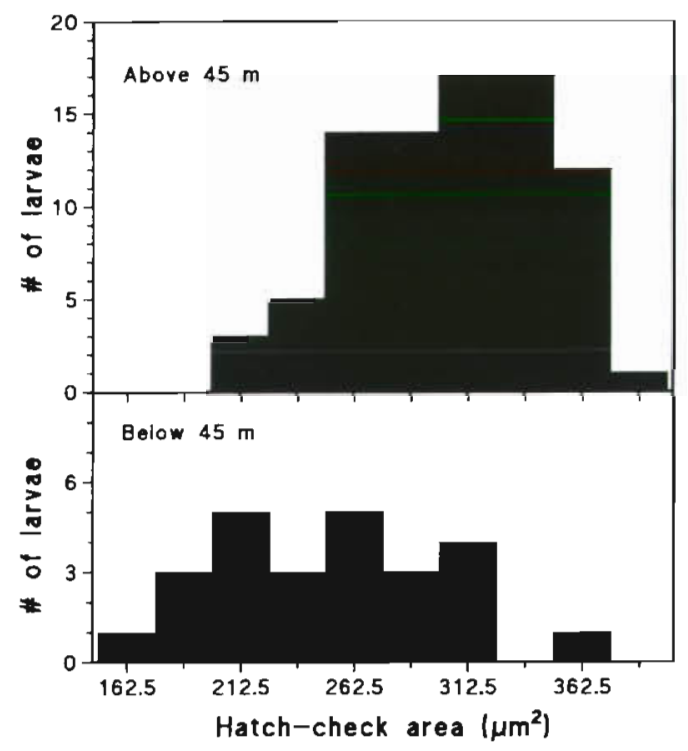

Fig. 4. Frequency distribution of otolith hatch-check areas of Jarvae $<14 \mathrm{~d}$ caught below and above $45 \mathrm{~m}$. (below $\mathrm{n}=25$, above $\mathrm{n}=83$ ) face $\left(\leq 45 \mathrm{~m}\right.$, mean area $\left.=301 \mu \mathrm{m}^{2}\right)$ and larvae still residing at hatching depth $\left(>45 \mathrm{~m}\right.$, mean area $\left.=261 \mu \mathrm{m}^{2}\right)$ (Kolmogorov-Smirnov, $Z=1.52, p=0.02$ ). This difference was not reflected in the larval standard lengths (4.93 $\mathrm{mm}$ vs $4.70 \mathrm{~mm}, t=1.33, \mathrm{df}=63, \mathrm{p}=0.18)$. The mean hatch-check areas of the larvae in the surface layers were similar on all 4 cruises (range: 305 to $308 \mu^{2}$ ).

Fig. 5 shows a scatter plot and least squares regression lines of instantaneous protein growth rate (Gpi) versus hatch-check area for 37 larvae. A productmoment correlation revealed a weak correlation between hatch-check area and Gpi $(r=0.38$, df $=36$, $p=0.019$, line $A)$. If we excluded the yolk-sac larvae $(<7 \mathrm{~d})$, which due to ontogenetic changes in metabolism inevitably have fluctuating $\mathrm{Gpi}$, the correlation improved $(\mathrm{r}=0.52, \mathrm{df}=22, \mathrm{p}=0.010$, line $\mathrm{B})$.

\section{DISCUSSION}

The analyses performed in this study suggest that the factors controlling otolith size at hatch influence the chances of survival for Baltic cod larvae. The larvae surviving the first-feeding period had hatch-checks larger than, or close to, the overall mean. The loss of larvae with small hatch-checks was pronounced around Day 12 to 13 , which corresponds to the age when starved larvae from laboratory studies are found to die (Buckley 1979, Ellertsen et al. 1980, Grønkjær et al. 1997). The size range of these surviving larvae's hatch-checks was within the range found for the younger larvae, indicating that the survivors originated from a population with hatch-check size distribution similar to the one observed for young larvae

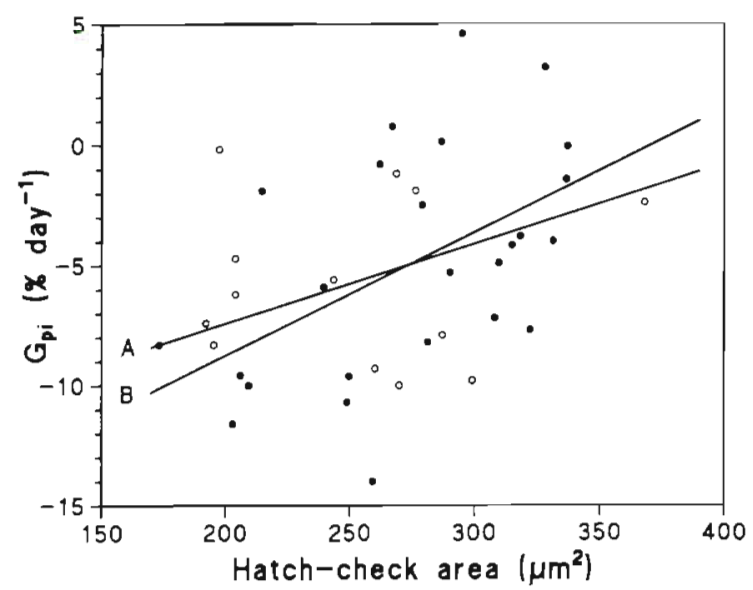

Fig. 5. Instantaneous protein growth rate (Gpi) versus hatchcheck area for 37 larvae. Open circles are larvae $<8 \mathrm{~d}$ old, and solid squares are larvae $\geq 8$ d old. (A) Least-squares regression tor all larvae. (B) Least squares regression for larvae $\geq 8 \mathrm{~d}$.

Both lines are significantly different from $0(p<0.05)$ 
( $\leq 13 \mathrm{~d}$ ). It is not likely that the increase in check size with age can be attributed to differences in incubation environment (temperature and oxygen) between young and old larvae. This could have been the case if larvae from only one sampling occasion had been used, and the spread in larval ages was large. Here, a mixture of young and old larvae was caught on all 4 cruises. Thus, in most cases, the young larvae from one cruise were comparable to the old larvae from the next cruise with regard to environmental exposure. Furthermore, Miller et al. (1999) did not find that inclusion of a temperature term added significant explanatory power to their otolith size standard length at hatch models. Likewise, an exploratory multiple regression performed on our data using age, depth and estimated temperature at hatch as predictors of hatch-check area did not include temperature as a significant predictor ( $p>0.05$ ) (not shown). However, these results could be biased due to the random effects of temperature in the regression.

In the examination of hatch-check sizes in relation to the vertical migration undertaken by first-feeding Baltic cod larvae (Wieland et al. 1994, Grønkjær et al. 1997), we excluded older larvae in order to keep the surface and deep group relatively homogeneous with regard to age. It has been suggested that the ability of cod to migrate towards the optimum feeding conditions near the surface is dependent on larval characteristics such as hatching size, yolk reserves, density and swimming ability, as well as environmental factors (Nissling et al. 1994b, Waller \& Rosenthal 1995, Gronkjær \& Wieland 1997). We found that the successful larvae (i.e. larvae in the surface layers) had significantly larger hatch checks than the ones found at depth. This vertical migration may be one of the specific processes determining the distribution of hatchcheck sizes with age, by acting as a bottleneck separating viable and moribund larvae.

Larval protein growth rates, calculated on the basis of RNA/DNA-ratios using the formula of Buckley (1984), were weakly correlated with the hatch check sizes. However, the analysis was performed on a small number of larvae and included a broad spectrum of developmental stages, which could blur any relationship between the 2 variables. Accordingly, this variability around the regression line was reduced when we limited the analysis to larvae that presumably had commenced feeding (i.e. $>7$ d). These regressions show that a proportion of the variation in protein growth rate can be explained by the factors controlling otolith hatch-check size.

We used the area of the hatch-check as our preferred size measure as opposed to linear measurements in our study. The hatch checks were often elliptical, thus the use of simple diameter measurements may be drawn into question. Nevertheless, the hatch-check diameters measured in this study were comparable to the sizes reported by Geffen (1995). Geffen also tested for hatch-check size-selective survival in laboratory reared cod larvae. Although the mean check diameter increased with age, the increase was not significant. In her analysis, however, only larvae aged 2 to $12 \mathrm{~d}$ were included. Our study indicates that differential mortality was most pronounced after Day 12 . Hence, selective mortality might also have occurred in Geffen's (1995) study but at later stages than those included in the analysis. Our results are consistent with the observations of superior survival in larvae with large hatchchecks reported in Meekan \& Fortier (1996). In their study, selection of larvae with large hatch-checks was not statistically evident until the cod were 40 to $60 \mathrm{~d}$ old. They suggest this resulted from the small number of younger larvae (i.e. $<40 \mathrm{~d}$ old) analysed.

What has then been selected for in the present study? The relationship between otolith and larval size at hatch is appealing, but not supported by the literature. Miller et al. (1999) concluded that the relationship is too weak to allow for accurate comparisons of size distribution at hatch between survivors and the original population unless the directional selection is very strong.

Observations similar to ours, i.e., that factors controlling otolith size are influencing survival and growth, have been made for salmonid fry (Titus \& Mosegaard 1991, Metcalfe et al. 1992). However, the underlying mechanisms remain elusive. Crucial to the understanding of these mechanisms is the physiology of otolith growth. Otolith growth is assumed to reflect somatic growth, but decoupling of the 2 has been found due to temperature and growth rate (Mosegaard et al. 1988, Secor \& Dean 1989, 1992). These findings have been taken to support the hypothesis that otolith growth mirrors metabolic rate (e.g. Mosegaard 1990, Titus \& Mosegaard 1991).

If the pattern we observe is determined by intrinsic factors relating to metabolic performance, we would expect large otoliths in embryos with high metabolic rate, and a high metabolic rate is thought to be a prerequisite for superior growth (Mosegaard 1990, Titus \& Mosegaard 1991). Nevertheless, the success of yolksac larvae with high metabolic rates may still be crucially dependent on maternal effects such as large egg size, as they would convert yolk at a high rate and, thus, rapidly deplete their endogenous food supply (Conover \& Schultz 1997).

The environmental variations observed within the cruise were mainly changes in oxygen content. Low ambient oxygen content may reduce the metabolic rate of an embryo (Rombough 1986) and, consequently, otolith growth. This might suggest that the 
larvae with small hatch-checks could be individuals incubated at sub-optimal oxygen conditions. The oxygen content decreases towards the bottom in the deep water basins of the Baltic Sea, which means that the oxygen available for a developing embryo is affected by the vertical position of the egg. Furthermore, maternal effects could add to this pattern. Large females have been shown to produce larger eggs than smaller females (Grauman 1964, Kjesbu 1989), and because small eggs are denser than the large eggs (Nissling et al. 1994a, Nissling \& Vallin 1996) these would be located at greater depth and, consequently, in waters with a lower oxygen content. Hence, 2 mechanisms could account for the differing hatch-check sizes, namely egg size per se and the effect of size on the eggs vertical distribution.

In this study, we found that larvae with larger hatchchecks apparently have a higher chance of survival than the average larvae. We have also suggested that the migration from hatching depth to the surface layers may be a 'bottleneck' separating viable and moribund larvae. In addition, we showed a weak correlation between hatch-check size and growth rate. Whether this linkage is due to advantages of being large at hatch, or of having a high metabolic rate is uncertain. Until the mechanisms underlying otolith growth are better understood, we are not able to determine the basis for selection of large hatch-checks underlying the non-random mortality of Baltic cod larvae.

Acknowledgements. This work was supported by founding from the Danish National Science Research Council (PG) and the EU (Baltic CORE, grant no. AIR2 CT94 1226). Thanks are due to Drs D. Schnack, K. Wieland and F. W. Köster for support during the field investigations. Thanks also to $\mathrm{Dr} \mathrm{K}$. Richardson, Dr A. Folkvord, Dr E. E. Nielsen, R. Nielsen., Dr $M$. St. John and the 4 anonymous reviewers whose comments significantly improved this manuscript. Special thanks are due to the able crew on FS 'Alkor'.

\section{LITERATURE CITED}

Bailey KM, Houde ED (1989) Predation on eggs and larvae and the recruitment problem. Adv Mar Biol 25:1-83

Buckley LJ (1979) Relationships between RNA-DNA ratio, prey density, and growth rate in Atlantic cod (Gadus morhua) larvae. J Fish Res Bd Can 36:1497-1502

Buckley LJ (1984) RNA/DNA ratio: an index of larval fish growth in the sea Mar Biol 80:291-298

Buckley LJ, Smigielski AS, Halavik TA, Caldarone EM, Burns BR, Laurence GC (1991) Winter flounder Pseudopleuronectes americanus reproductive success. II. Effects of spawning time and female size on size, composition and viability of eggs and larvae. Mar Ecol Prog Ser 74:125-135

Campana SE (1996) Year-class strength and growth rate in young Atlantic cod Gadus morhua Mar Ecol Prog Ser 135 $21-26$

Campana SE, Neilson JD (1985) Microstructure of fish otoliths. Can J Fish Aquat Sci 42:1014-1032
Chambers RC, Leggett, WC (1996) Maternal influences on variation in egg sizes in temperate marine fishes. Am Zool 36:180-196

Conover DO. Schultz ET (1997) Natural selection and the evoIution of growth rate in the early life history: what are the trade-offs? In: Chambers RC. Trippel EA (eds) Early life history and recruitment in fish populations. Fish and Fisheries Series 21, Chapmann \& Hall, London, p 305-332

Ellertsen B, Solemdal P, Strømme T, Tilseth S, Westgård T Moksness E, Øiestad V (1980) Some biological aspects of cod larvae (Gadus morhua L.). Fiskerdir Skr Ser Havunders 17:29-47

Geffen A (1995) Growth and otolith microstructure of cod (Gadus morhua L.) larvae. J Plankton Res 17:783-800

Grauman GB (1964) The importance of the size of the eggs of the Baltic cod for the survival of foetuses. ICES Comm Meet 1964 (Gadoid Fish Committee) 85:1-5

Grønkjær P, Wieland K (1997) Ontogenetic and environmental effects on vertical distribution of cod larvae in the Bornholm Basin, Baltic Sea. Mar Ecol Prog Ser 154:91-105

Grønkjær P. Clemmesen C. St. John M (1997) Nutritional condition and vertical distribution of Baltic cod larvae. J Fish Biol 51 (Supplement A):352-369

Heath MR (1992) Field investigations of the early life stages of marine fish. Adv Mar Biol 28:1-174

Houde ED (1989) Comparative growth, mortality, and energetics of marine fish larvae: temperature and implied latitudinal effects. Fish Bull US 87:471-495

Kjesbu OS (1989) The spawning activity of cod, Gadus morhua L. J Fish Biol 34:195-206

Korhola A, Solemdal P, Bratland P, Fonn M (1996) Variation in annual egg production in individual captive Atlantic cod (Gadus morhua) Can J Fish Aquat Sci 53:610--620

Leggett WC, Deblois E (1994) Recruitment in marine fishes: is it regulated by starvation and predation in the egg and larval stages? Neth J Sea Res 32: 119-134

Letcher BH, Rice JA, Crowder LB, Rose KA (1996) Variability in survival of larval fish: disentangling components with a generalized individual-based model. Can J Fish Aquat Sci 53:787-801

Meekan MG, Fortier L (1996) Selection for fast growth during the larval life of Atlantic cod Gadus morhua on the Scotian Shelf. Mar Ecol Prog Ser 137:25-37

Metcalfe NB. Wright PJ, Thorpe JE (1992) Relationships between social status, otolith size at first feeding and subsequent growth in Atlantic salmon (Salmo salar). J Anim Ecol 61:585-589

Miller TJ, Herra T, Leggett WC (1999) The relationship between larval size and otolith size at hatch in Atlantic cod (Gadus morhua). Fish Bull US 97:294-305

Mosegaard $\mathrm{H}$ (1990) What is reflected by otolith size at emergence? A reevaluation of the results in West and Larkin (1987). Can J Fish Aquat Sci 47:225-228

Mosegaard H, Svedäng $H$, Taberman, K (1988) Uncoupling of somatic and otolith growth rates in Arctic char (Salvelinus alpinus) as an effect of differences in temperature response. Can J Fish Aquat Sci 45:1514-1524

Nissling A, Vallin L (1996) The ability of Baltic cod eggs to maintain neutral buoyancy and the opportunity for survival in fluctuating conditions in the Baltic Sea. J Fish Biol 48:217-227

Nissling A, Kryvi H, Vallin L (1994a) Variation in egg buoyancy of Baltic cod Gadus Morhua and its implications in prevailing conditions in the Bältic Sea. Mar Ecol Prog Ser 110:67-74

Nissling A, Solemdal P, Svensson M, Westin L (1994b) Survival, activity and feeding ability of Baltic cod (Gadus 
morhua) yolk-sac larvae at different salinities. J Fish Biol 45:435-445

Paynter KT, DiMichele L, Hands SC, Powers DA (1991) Metabolic implications of Ldh-B genotype during early development in Fundulus heteroclitus. J Exp Zool 257:24-33

Plikshs M, Kalejs M, Grauman G (1993) The influence of environmental conditions and spawning stock size on the yearclass strength of the eastern Baltic cod. ICES Comm Meet $1993 / \mathrm{J}: 22$

Rombough PJ (1986) Mathematical model for predicting the dissolved oxygen requirements of steelhead (Salmo gairdneri) embryos and alevins in hatchery incubators Aquaculture 59:119-137

Secor DH, Dean JM (1989) Somatic growth effects on the otolith-fish size relationship in young pond-reared striped bass, Morone saxatalis. Can J Fish Aquat Sci 46:113-121

Secor DH, Dean JM (1992) Comparison of otolith-based backcalculation methods to determine individual growth histo-

Editorial responsibility: Otto Kinne (Editor),

Oldendorf/Luhe, Germany ries of larval striped bass Morone saxatilis. Can J Fish Aquat Sci 49:1439-1454

Stevenson DK, Campana SE (eds) (1992) Otolith microstructure examination and analysis. Can Spec Publ Fish Aquat Sci 117:126

Titus RG, Mosegaard H (1991) Selection for growth potential among migratory Brown trout (Salmo trutta) fry competing for territories: evidence from otoliths. Can J Fish Aquat Sci 48:19-27

Vallin L, Nissling A (1995) Egg and larval quality of Baltic cod (Gadus morhua). Medd Havsfiskelab Lysekil 327 : 108-114

Waller U, Rosenthal H (1995) The migratory behaviour of yolk-sac larvae of cod, Gadus morhua. ICES Comm Meet 1995/L:14

Wieland K, Waller U, Schnack D (1994) Development of Baltic cod eggs at different levels of temperature and oxygen content. Dana 10:163-177

Submitted: October 9, 1997; Accepted: November 26, 1998

Proofs received from author(s): April 22, 1999 